\title{
Air pollutants emissions from cattle in Galicia, Spain
}

\author{
M. Morán, J. A. Souto-Gonzalez \& M. Dios \\ Department of Chemical Engineering, \\ University of Santiago de Compostela, Spain
}

\begin{abstract}
Cattle production has a significant contribution to the total GHGs emissions, particularly, $\mathrm{CH}_{4}$ and $\mathrm{N}_{2} \mathrm{O}$. Also, other air pollutants, as $\mathrm{NH}_{3}$ and $\mathrm{NMVOC}$, are emitted. As a European region with significant dairy and beef farms, Galicia (NW of Spain) is suitable to assess the contribution of cattle production to the regional livestock air pollutants emissions (namely, EMEP S10 in SNAP classification), considering up to date activity data. Therefore, the objective of this study is to update the annual emissions by dairy and beef cattle in Galicia, according to the different bottom-up methodologies: IPCC (Tier 1 and Tier 2) and EMEP/CORINAIR. This inventory is compared to both EMEP and E-PRTR emissions inventories: $\mathrm{NH}_{3}$ cattle emissions are around half of EMEP S10, taking into account that EMEP S10 also includes other agriculture sources. NMVOCs cattle emissions are strongly higher than EMEP S10 emissions; moreover, there is no agreement in this region between S10 EMEP emissions and cattle farms geographical distributions. Besides E-PRTR does not include cattle farms emissions, $\mathrm{CH}_{4}$ and $\mathrm{NH}_{3}$ cattle emissions are 900 and 8 times higher than total current E-PRTR declared emissions at the same region: to add cattle farms in E-PRTR activities is highly recommended.
\end{abstract}

Keywords: cattle emissions, bottom-up inventory, EMEP, PRTR.

\section{Introduction}

Ruminants are the most important livestock producers [1] of greenhouse gases (GHGs), due to their larger mass, large population and rumen fermentation [2]. Methane is mainly produced by anaerobic bacterial decomposition of organic compounds in feed which is emitted as a product of enteric fermentation, and 
from decomposition of manure under anaerobic conditions [3]. $\mathrm{N}_{2} \mathrm{O}$ is emitted from manure as an intermediate product of nitrification/denitrification $\mathrm{N}_{2} \mathrm{O}$ is emitted from manure and mineral fertilization as an intermediate product of nitrification/denitrification. The availability of inorganic $\mathrm{N}$ in soil and anoxic conditions promote $\mathrm{N}_{2} \mathrm{O}$ emissions [4]. In Spain, livestock contributes over $35 \%$ of $\mathrm{CH}_{4}$ emissions, of which $60 \%$ are from cattle [5].

Local agricultural emissions significantly contribute to atmospheric reactive nitrogen loads in terrestrial ecosystems. This contribution is due to deposition of dry ammonia gas phase resulting from local cattle production [6]. Emissions of $\mathrm{NH}_{3}$ and NMVOCs arise from excreta of agricultural livestock deposited in and around buildings and collected as liquid slurry, solid manure or litter-based farmyard manure. These emissions are in the stables, yards and pastures, during storage and deposition as fertilizer.

From the Spanish regions, Galicia (NW of Spain) is potentially the region with most potentially problems in Spain, with the highest animals and farms densities, cows feeding based in wet forage, and a moderate milk production per cow $[7,8]$. Also, pits for manure storage are usually undersized, with common permeability problems [9].

Based in both the number and density of cattle in Galicia, and the specific characteristics of their farms, this study is focused in establishing the ruminant emissions production in Galicia, in order to obtain a regional emissions inventory. Also, an assessment of this regional inventory is done by comparison against both EMEP and E-PRTR (European Pollutant Release and Transfer Register inventories); taking into account their different classification methods of cattle emissions.

\section{Methodology and Emissions Factors (EFs) estimation}

Ruminant production emissions inventories are based in the emissions factors (EFs) derived from the process analysis. Different methodologies were proposed, depending on the complexity of the processes considered in a typical ruminant's farm. About GHGs emissions, IPCC [1] provides guidelines for $\mathrm{CH}_{4}$ and $\mathrm{N}_{2} \mathrm{O}$ emissions estimations from ruminant production, following two different methodologies. Tier 1, is based in the use of an average emission factor per animal for every type of animal. Tier 2 is a more complex methodology, derived from a comprehensive process analysis of different cattle farms. This method requires more detailed and specific data depending on each country or region or each animal category: energy needs, food intake and methane conversion rates, type of housing and manure storage systems, length of the grazing period, $\mathrm{N}$ excretion rates, milk production and composition, feed intake and proportion of forage in the diet.

According to IPCC [1] guidelines in Tier 2, only livestock categories available population data enough were considered. $\mathrm{CH}_{4}$ and $\mathrm{N}_{2} \mathrm{O}$ emissions were partitioned, as each livestock group was subdivided into $\mathrm{CH}_{4}$ emissions from enteric fermentation and manure management, as well as direct $\mathrm{N}_{2} \mathrm{O}$ emissions from manure management and managed soils. In addition, indirect $\mathrm{N}_{2} \mathrm{O}$ 
emissions from $\mathrm{N}$ leaching and runoff, and from atmospheric deposition of volatilized N, were calculated.

Fig. 1 shows a basic scheme of calculation and comparison of bovine sector emissions following the two different IPPC methods, Tier 1 (simplified) and Tier 2 (detailed). Very different levels of complexity and required datasets between both methods are highlighted.

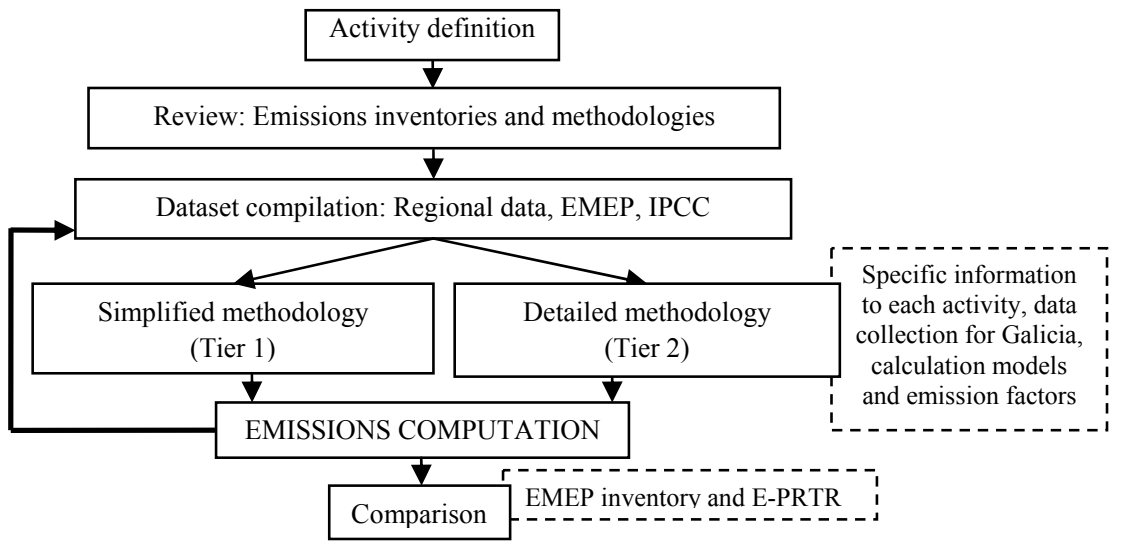

Figure 1: Calculation procedure of cattle sector emissions.

About none-GHGs emissions, $\mathrm{NH}_{3}$ and NMVOC emissions estimation follows EMEP/CORINAIR methodology [10], with updated emissions factors for animal husbandry and manure management [11]. This methodology distinguishes four main sources of cattle emissions: shelter livestock, manure storage, manure application in field, and manure deposited during grazing.

\section{Results}

\section{1 $\mathrm{CH}_{4}$ emissions}

Table 1 shows the calculated $\mathrm{CH}_{4}$ EFs in Galicia for year 2009 applying Tier 1 and Tier 2 methodologies. About $\mathrm{CH}_{4}$ production, when manure is either stored or processed as a liquid, it decomposes anaerobically and produces significant amounts of $\mathrm{CH}_{4}$.

In Galicia the main $\mathrm{CH}_{4}$ emission source is enteric fermentation, contributing $83 \%$ (using Tier 1) and 65\% (using Tier 2) of total $\mathrm{CH}_{4}$ emissions in 2009 (Fig. 2). However, the largest differences between Tier 1 and Tier 2 emissions (Table 1) are mainly due to manure management, as Tier 2 includes a detailed manure management model. In fact, several nutritional factors have been identified affecting the enteric $\mathrm{CH}_{4}$ production rate in ruminants: the level of DM intake and the animal productivity are key factors. Others are the feed concentrate composition, the maturity of harvested forages and the use of maize silage as a complement of grass silage. 
Table 1: $\quad \mathrm{CH} 4 \mathrm{EF}\left(\mathrm{kg} \mathrm{head}^{-1} \mathrm{yr}^{-1}\right)$ and emissions $\left(\mathrm{Gg} \mathrm{yr}^{-1}\right)$ from enteric fermentation and manure management in Galicia (2009), calculated as Tier 1 and Tier 2 [1].

\begin{tabular}{ccccccc}
\hline & \multicolumn{3}{c}{ Tier 1 } & \multicolumn{3}{c}{ Tier 2 } \\
\cline { 2 - 7 } Livestock category & $\mathrm{EF}_{\text {ef }}$ & $\mathrm{EF}_{\mathrm{mm}}$ & Emiss. & $\mathrm{EF}_{\mathrm{ef}}$ & $\mathrm{EF}_{\mathrm{mm}}$ & Emiss. \\
\hline Mature Dairy Cow & 109 & 27 & 50.69 & 82.65 & 45.59 & 30.82 \\
Other Mature Cattle & 57 & 8 & 22.28 & 65.18 & 28.99 & 22.36 \\
Growing Cattle & 57 & 8 & 16.52 & 52.75 & 33.94 & 13.42 \\
\hline TOTAL & & & 89.50 & & 66.60 \\
\hline
\end{tabular}

Considering Tier 2 methodology, dairy cattle farms in Galicia have a $\mathrm{CH}_{4} \mathrm{EF}$ of $82.65 \mathrm{~kg} \mathrm{CH}_{4}$ head $^{-1} \mathrm{yr}^{-1}$, which is lower than other farms in previous studies: Vermorel et al. [12] obtained $118 \mathrm{~kg} \mathrm{CH}_{4}$ head $^{-1} \mathrm{yr}^{-1}$, when milk yield ranged from 5000 to $10000 \mathrm{~kg}$ milk head $\mathrm{yr}^{-1}$ (in Galicia, $5400 \mathrm{~kg}$ milk head ${ }^{-1} \mathrm{yr}^{-1}$ ); Berra et al. [13] reported that the average emission of $\mathrm{CH}_{4}$ per animal in dairy cattle is much higher than in beef cattle: 91.79 and $51.78 \mathrm{~kg} \mathrm{CH}_{4}$ head $^{-1} \mathrm{yr}^{-1}$, respectively. DeRamus et al. [14] provided values ranged from $83 \mathrm{~kg} \mathrm{CH}$ head $\mathrm{yr}^{-1}$ for beef cows to $95 \mathrm{~kg} \mathrm{CH}_{4}$ head $^{-1} \mathrm{yr}^{-1}$ for dairy cows; Merino et al. [15] obtained $107 \mathrm{~kg} \mathrm{CH}_{4}$ head $^{-1} \mathrm{yr}^{-1}$ and $60 \mathrm{~kg} \mathrm{CH}_{4}$ head $^{-1} \mathrm{yr}^{-1}$ for dairy and beef cattle, respectively, under conditions very similar to Galicia.

Those differences can be explained by specific Galicia conditions. First, EF calculated values (Table 1) from Tier 2 are higher than Tier 1, except to dairy cattle EF from enteric fermentation, since these animals are mainly fed with high concentrated diets with high digestibility, which results in lower enteric $\mathrm{CH}_{4} /$ head emission. About manure management, estimated Tier 2 dairy cattle $\mathrm{CH}_{4} \mathrm{EF}$ in Galicia is higher than default Tier $1 \mathrm{EF}$, because in this region some beef cattle farms manage manure in a liquid form, resulting in an EF increase.

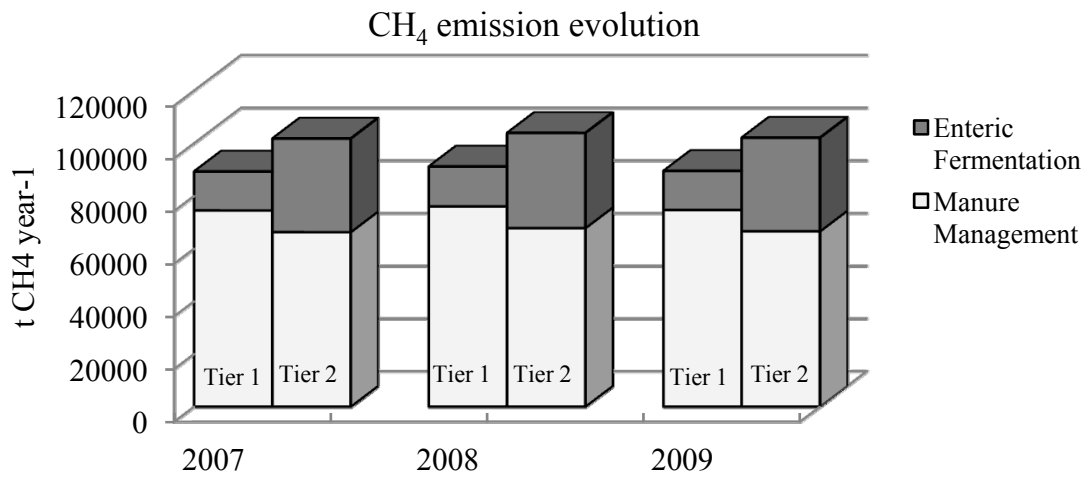

Figure 2: $\mathrm{CH}_{4}$ emissions evolution from enteric fermentation and manure management, using Tier 1 and Tier 2. 
Fig. 2 shows the different contributions from enteric fermentation and manure management to the total emission of $\mathrm{CH}_{4}$. The reduction in $\mathrm{CH}_{4}$ emissions from dairy and beef cattle in 1996-2006 period is mainly due to the $32 \%$ increase of number of cows per farm [17]. Also, a decrease (15\%) in the dairy and beef cattle in that period was later reversed in the $2007-2010$ period by a small increase in beef cattle $(2 \%)[7,17]$.

\section{2 $\mathrm{N}_{2} \mathrm{O}$ emissions}

For $\mathrm{N}_{2} \mathrm{O}$, Tier 2 Galician emissions are lower than Tier 1 (Table 2) although differences are lower than in the case of $\mathrm{CH}_{4}$ emissions. The amount of excreted nitrogen (Nexc) depends on dry matter intake and protein concentration diet digestibility. Although the diet effect can reduce $\mathrm{CH}_{4}$ emissions, GHGs Global Warming Potential (GWP) be offset by increased emissions of $\mathrm{N}_{2} \mathrm{O}$ and $\mathrm{CO}_{2}$ [18] and, $\mathrm{N}_{2} \mathrm{O}$ increment is not favourable.

Table 2: $\quad \mathrm{N}_{2} \mathrm{O}$ EFs $\left(\mathrm{kg} \mathrm{hd}^{-1} \mathrm{yr}^{-1}\right)$, emissions $\left(\mathrm{Gg} \mathrm{yr}^{-1}\right)$ and excreted nitrogen (Nexc) $\left(\mathrm{kg} \mathrm{N} \mathrm{hd}^{-1} \mathrm{yr}^{-1}\right)$ in Galicia, year 2009, calculated as Tier 1 and Tier $2[1]$.

\begin{tabular}{ccccccc}
\hline & \multicolumn{2}{c}{ Tier 1 } & \multicolumn{4}{c}{ Tier 2 } \\
\cline { 2 - 7 } Livestock category & Emissions & EF $_{\mathrm{mm}}$ & Nexc & Emissions & EF $_{\mathrm{mm}}$ & Nexc \\
\hline Mature Dairy Cow & 8.25 & 22.13 & 79.72 & 0.969 & 2.6 & 69.62 \\
Other Mature Cattle & 33.56 & 97.90 & 84.65 & 17.22 & 50.2 & 54.01 \\
Growing Cattle & 67.29 & 26.47 & 22.89 & 15.50 & 61.0 & 65.56 \\
TOTAL & 48.54 & & & 33.70 & & \\
\hline
\end{tabular}

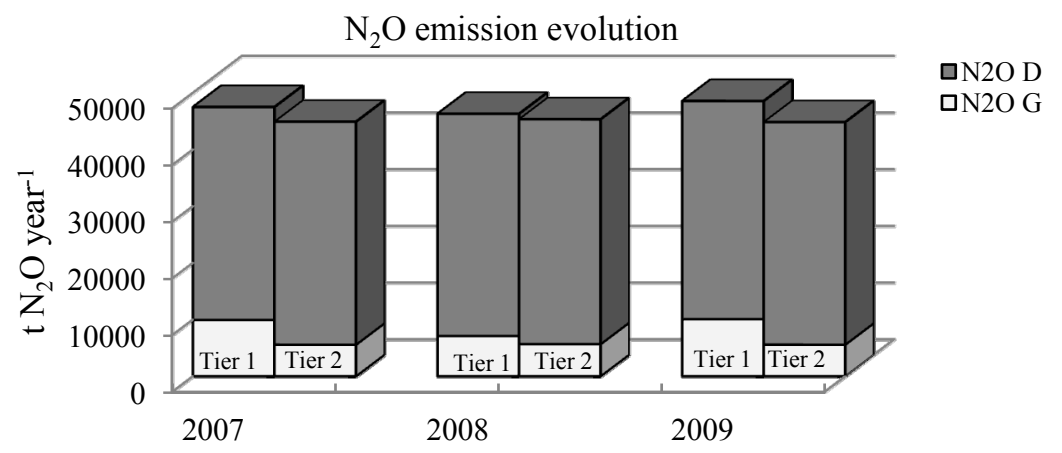

Figure 3: $\quad \mathrm{N}_{2} \mathrm{O}$ cattle emissions evolution in Galicia, using Tier 1 and Tier 2.

Fig. 3 shows $\mathrm{N}_{2} \mathrm{O}$ emissions evolution and comparison of Tier 1 and, also, Tier 2; this last method takes into account that $6.2 \%$ of dairy cattle farms in 
Galicia manage manure based on solid systems, resulting in higher $\mathrm{N}_{2} \mathrm{O}$ EF from manure management, as aerobic conditions in manure storage can increase $\mathrm{N}_{2} \mathrm{O}$ losses [19]. When the beef cattle farms graze all year, it increases the risk of higher $\mathrm{N}_{2} \mathrm{O}$ losses. Apart from manure storage, estimated $\mathrm{N}$ excretion also affects EF calculation. As a result (Fig. 4), the contribution of beef cattle to $\mathrm{N}_{2} \mathrm{O}$ emissions in this region has become important in recent years, as many farmers have changed from dairy to beef cattle production.

\subsection{NMVOC and $\mathrm{NH}_{3}$ emissions}

EFs based in Hobbs et al. [20] (Table 3) were applied over the Galician region cattle, considering separately both dairy and none-dairy cattle. Although NMVOC EF for dairy cattle is twice the none-dairy cattle EF, the corresponding NMVOC emissions are quite similar in Galicia, showing the strong weight of none-dairy cattle in this region.

Table 3: $\quad$ EFs $\left(\mathrm{kg} \mathrm{head}^{-1} \mathrm{yr}^{-1}\right)$ and emissions $\left(\mathrm{Gg} \mathrm{yr}^{-1}\right)$ for NMVOC and $\mathrm{NH}_{3}$ in Galicia, year 2009.

\begin{tabular}{ccccccc}
\hline NFR & NFR Name & $\begin{array}{c}\mathrm{EF} \\
\text { for NMVOC }\end{array}$ & $\begin{array}{c}\text { NMVOC } \\
\text { emissions }\end{array}$ & $\begin{array}{c}\mathrm{EF} \\
\text { for } \mathrm{NH}_{3}\end{array}$ & $\begin{array}{c}\mathrm{NH}_{3} \\
\text { emissions } \\
\text { Tier 1 }\end{array}$ & $\begin{array}{c}\mathrm{NH}_{3} \\
\text { emissions } \\
\text { Tier 2 }\end{array}$ \\
\hline 4.B.01.a & Dairy cattle & 13.6 & 5.07 & 39.3 & 14.6 & 13.0 \\
4.B.01.d & $\begin{array}{c}\text { Non-dairy cattle } \\
\text { TOTAL }\end{array}$ & 7.4 & 4.42 & 13.4 & 8.0 & 6.47 \\
& & 9.50 & & 22.65 & 19.50 \\
\hline
\end{tabular}

In Galicia, the pits for manure storage are undersized in most farms, presenting in many cases permeability problems; also, the lack of covers causes the rainwater inlet [9]. The most typical manure management system in Galicia is the liquid system. EF has been calculated assuming that manure is stored prior to surface application, without quick incorporation. Only Tier 2 considers different manure management system in EF calculation.

Although the relative difference between Tier 1 and Tier $2 \mathrm{NH}_{3}$ emissions in the study region is low ( $11 \%$ and $19 \%$ for dairy and beef cattle), using Tier 2 the mass balance can be apply to check any error and, also, to analyze the sensitivity of the emissions to changes in the manure management. On the other hand, NMVOC emissions uncertainty can drive to very different results.

\subsection{Emissions geographical distribution}

An analysis of the spatial distribution of the new calculated emissions is feasible to explain their relationship to the farms geographical distribution of the farms in the study region. In this case, emissions were analysed using ArcGIS 9.3 [20], with a municipalities database (316 councils) as base map.

Fig. 4 shows the distribution of dairy and beef farms (Fig. 4a) in the study region. It can be compared to $\mathrm{CH}_{4}$ and $\mathrm{NH}_{3}$ emissions distribution (Fig. $4 \mathrm{~b}$ and 4c, respectively) with $\mathrm{CH}_{4}$ emissions obtained by Tier 2 methodology. 

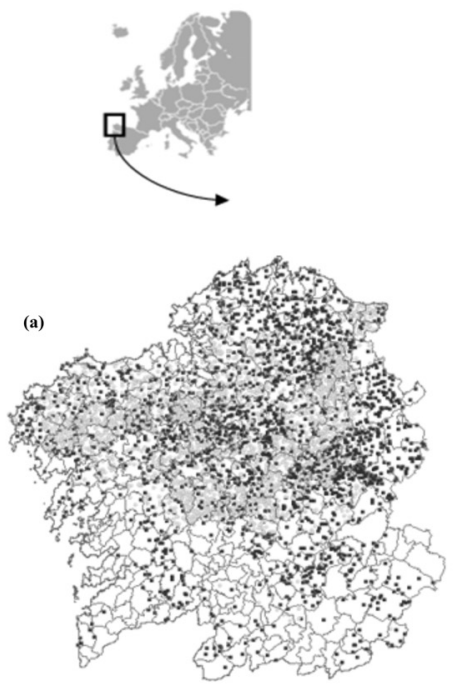

Distribution of dairy and beef farms

- 1 point $=100$ head

- Dairy cows

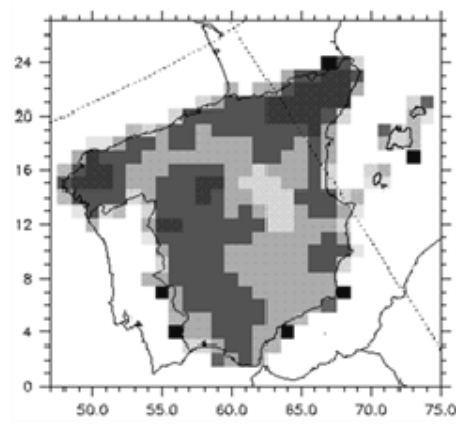

(d)

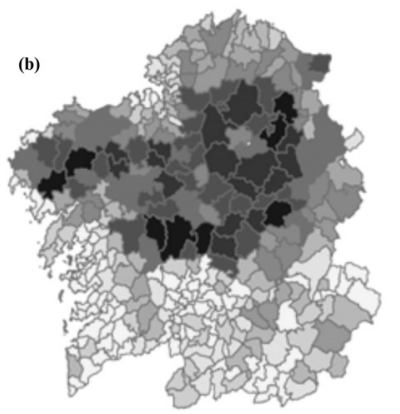

$\mathrm{CH}_{4}$ emissions (kg CH $\mathbf{C H}_{4} \cdot \mathrm{hd}^{-1}$ )
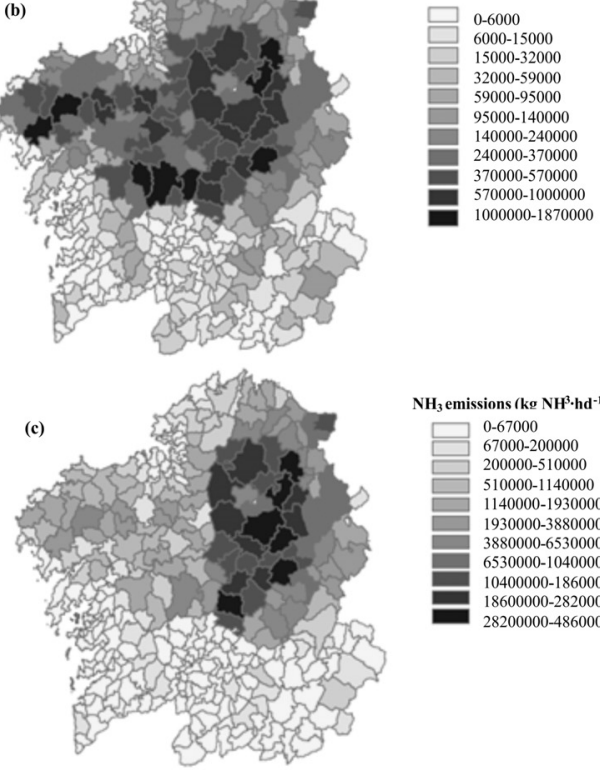

$\mathrm{NH}_{3}$ emissions $\left(\mathrm{kg} \mathrm{NH}^{3} \cdot \mathrm{hd}^{-1}\right)$

$\square \quad 0-67000$

67000-200000

200000-510000

$1140000-1930000$

1930000-3880000

3880000-6530000

$6530000-10400000$
$10400000-18600000$

$18600000-28200000$

$28200000-48600000$

Figure 4: (a) Geographical distribution of dairy and beef farms, bottom-up inventory (b) $\mathrm{CH} 4$ and (c) $\mathrm{NH}_{3}$ emissions in 2009 in Galicia by municipalities, and EMEP emissions of (d) NH3 and (e) NMVOC in tons (t) in 2009 for S10 - Agriculture sector [25].

As it is shown, the Southern part of this region has less cattle farms, and most of them are not dairy farms (which represent $80.7 \%$ of the total), with a few cattle per farms. Beef farms are mainly located in the Eastern-Northeastern part, with small-sized farms (20.68 head/farm). On the other hand, Western part of the region shows a well balanced number between dairy and beef farms, although dairy farms number is still higher. This irregular farms distribution is reflected in the pollutants emissions distribution, both in $\mathrm{CH}_{4}$ and $\mathrm{NH}_{3}$; with the highest values in the Northern half of the region, due to the higher density of farms and 
cattle. However, none significant differences are observed in the emissions distribution due to the different farms (dairy and beef) in the region.

Comparing this bottom-up inventory to EMEP, only EMEP $\mathrm{NH}_{3}$ emissions (Fig.4d) correspond to the animal's distribution (Fig.4a), but not the EMEP NMVOC emissions (Fig.4e).

\subsection{Bottom-up vs. standard European emissions inventories}

The reliability of calculated emissions in Galicia is compared to the corresponding activities, namely sectors, that include animal farms in both EMEP and PRTR emissions inventories, when available. Results will be compared to published data from EMEP Programme, highlighting the specific characteristics of the study area. Considering CORINAIR S10-Agriculture sector, namely EMEP S10 in the SNAP classification [22], it includes emissions from crops with fertilizer, crops without fertilizers, burning of stubble, straw, the use of pesticides and limestone and fugitive sources of PM, and, also, enteric fermentation and manure management regarding organic compounds for different types of livestock (including cows) [22]. Although EMEP S10 sector include these sources categories, livestock produces the largest emissions amount for $\mathrm{NH}_{3}$ and NMVOC. Therefore, a comparison of those pollutants emissions is feasible.

Figs 5 and 6 show the emissions total amounts over the study region from 1998 to 2010 for $\mathrm{NH}_{3}$ and NMVOC, respectively. Three different inventories were considered: New bottom-up emissions, original EMEP inventory [24], and an EMEP inventory updated in June-2012 [25].

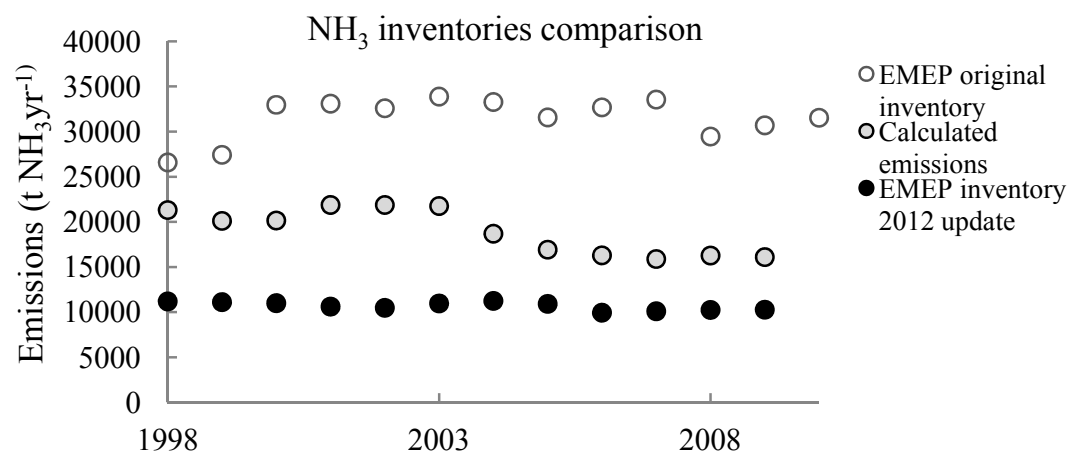

Figure 5: Comparison of calculated and EMEP S10 sector $\mathrm{NH}_{3}$ emissions at Galicia, considering both original and updated EMEP inventories.

As it is shown in Fig. 6, original EMEP inventory clearly underestimated $\mathrm{NH}_{3}$ emissions, compared to the new calculated cattle emissions inventory. However, updated EMEP S10 inventory provides higher emissions than cattle, which could be in agreement to the EMEP S10 sources. However, none of EMEP emissions are proportional to the number of cattle in Galicia year-to-year, so the EMEP 
emissions evolution is not in agreement to the new calculated cattle emissions; that could be a problem in terms of the EMEP S10 air pollution policy assessment.

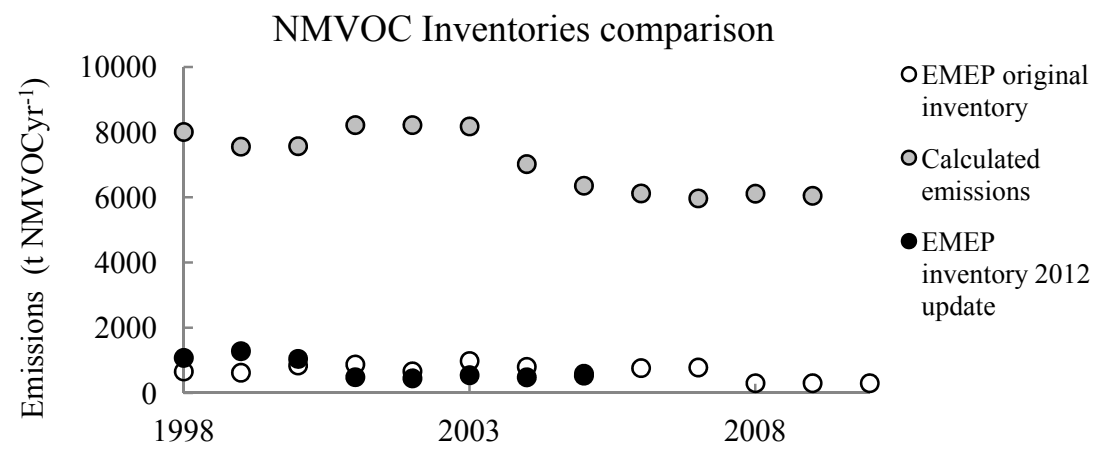

Figure 6: Comparison of calculated and EMEP S10 sector NMVOC emissions at Galicia, considering both original and updated EMEP inventories.

About NMVOC, the new bottom-up cattle emissions are systematically higher that both EMEP S10 emissions (original and updated). As all the NMVOC emissions were obtained following the same EMEP/CORINAIR methodology it is clear that the activity parameters used by EMEP inventory in this region are underestimated; this effect is especially significant as cattle emissions contribution to this EMEP S10 sector is higher than contributions from other animal farms (pigs, chickens...). As the second Spanish region in cattle number, and the first in cattle farms density, it is highly recommended to review the activity parameters applied by EMEP over this region and, also, over other European regions with high cattle density.

From this comparison, it is clear that cattle emissions have a strong contribution to EMEP S10 emissions. However, cattle farms are not included as activities in the E-PRTR (European Pollutants Releases and Transfer Register) inventory [25], which should also be systematically validated [27]. Activities in PRTR Category 7 cover livestock and intensive aquaculture; but, only pigs and poultry are included as livestock [28]. Comparing E-PRTR declared emissions (Category 7) and the new bottom-up emissions from cattle over the study region; significant differences arise, as follows,

- The new calculated $\mathrm{CH}_{4}$ emissions (cattle contribution) represent an increase of 900 times in E-PRTR category 7 emissions.

- For $\mathrm{NH}_{3}$, the cattle contribution is 8 times higher that category 7 E-PRTR declared emission.

Therefore, it is clear that both $\mathrm{CH}_{4}$ and $\mathrm{NH}_{3}$ cattle emissions must be included in E-PRTR emissions, apart from correcting both S10 EMEP emissions over this region. 


\section{Conclusions}

Cattle activities produce significant both GHGs and tropospheric pollutants emissions. However, cattle emissions uncertainty is associated not only to the emissions factors, but also to the associated activity and environmental parameters, which have different values depending on the manure management system, climate conditions and cattle feeding. Particularly, in Galicia cattle feeding are based on the use of wet forage (grass and maize silos) and manure management has become mostly liquid slurry due to high rainfall resulting in higher $\mathrm{CH}_{4}$ and $\mathrm{NH}_{3}$ emissions.

Considering GHGs emissions, Global Warming Potential (GWP) from $\mathrm{CH}_{4}$ and $\mathrm{N}_{2} \mathrm{O}$ cattle emissions represents $56 \%$ of the total GWP in this region. About this emissions uncertainty, $\mathrm{CH}_{4}$ emission estimated using Tier 2 (IPCC, 2006) is higher than using Tier 1 (IPCC, 2006), especially when manure management emissions are considered. Tier 2 results show that $65 \%$ of $\mathrm{CH}_{4}$ livestock emissions come from enteric fermentation. About $\mathrm{N}_{2} \mathrm{O}$ emissions, direct contribution (89\%) is the largest component. These large contributions of cattle to GHGs emissions in this region is explained by the amount of produced manure, because of the large size of both dairy and beef cattle populations.

About tropospheric pollutants, $\mathrm{NH}_{3}$ and NMVOC emissions were estimated using updated regional data. Compared to EMEP inventory, $\mathrm{NH}_{3}$ emissions value is twice the updated S10 EMEP sector emissions (July 2012), even though S10 sector not only includes cattle. Differences are even higher when NMVOC emissions are considered, with extremely low S10 EMEP values respect to the calculated NMVOC emissions. Also, cattle activities are not included in the E-PRTR emissions inventory, even though they should be the main contribution to $\mathrm{CH}_{4}$ and $\mathrm{NH}_{3}$ emissions in the IPPC Category 7.

\section{Acknowledgements}

This work was partially supported by Laboratorio de Medio Ambiente de Galicia (Xunta de Galicia), under contract "Management and Evaluation of the Galician PRTR emissions register" and research project "XIMERE/FUXIMERE" (10MDS009E, Xunta de Galicia).

\section{References}

[1] IPCC, 2006. IPCC Guidelines for national greenhouse gas inventories. Vol. 4. Agriculture, forestry and other land use. In: Eggleston, H.S., Buendia, L., Miwa, K., Ngara, T., Tanabe, K. Eds. Prepared by the National Greenhouse Gas Inventories Programme IGES, Hayama, Japan.

[2] USDA, 2004. U.S. Agriculture and Forestry Greenhouse Gas Inventory: 1990-2001. Global Change Program Office, Office of the Chief Economist, Washington, USA. www.usda.gov/oce/global change/gg inventory.htm. 
[3] Moss, A.R., Jounay, J.P., Newbold, J., 2000. Methane production by ruminants: its contribution to global warming. Ann. Zootech. 49, 231-253.

[4] Fabbri, C., Valli, L., Guarino, M., Costa, A., Mazzotta, V. 2007. Ammonia, methane, nitrous oxide and particulate matter emissions from two different buildings for laying hens. Biosyst. Eng. 97, 441-455.

[5] UNFCCC, 2007. National emission inventory based on IPCC and UNFCCC reference manual (in Spanish). Submissions 2007, Spain. CRF. Inventory 2005. www.unfccc.int/national reports/annex i ghg inventories/national inventories submissions/items/3929.php.

[6] Hertel, O., Geels, C., Frohn, L.M., Ellermann, T., Skjøth, C.A., Per Løfstrøm, Jesper H.C., Andersen, H.V., Peel, R.G. 2012. Assessing atmospheric nitrogen deposition to natural and semi-natural ecosystems. Experience from Danish studies using the DAMOS. Atmospheric Environment 1-10.

[7] CMR. 2005. Ministry of Rural Environment. Galician Sanitation Campaign 2005 and administrative records. http://mediorural.xunta.es/institucional/ estatisticas/gando_bovino/.

[8] Blas, C., García-Rebollar, P., Cambra-López, M., Torres, A.G. 2008. Ruminants contribution to emissions of greenhouse gases. FEDNA specialization course.

[9] PXRAG. 2001. Waste management plan of agrarian Galicia. Department of Environment, Department of Agricultural Policy and rural development. Government of Galicia.

[10] EEA. 2003. EMEP/CORINAIR.Transboundary acidification and eutrophication and ground level ozone in Europe: Unified EMEP model description. Status report 1/03 Part I. European Monitoring and Evaluation Programme.

[11] EEA. EMEP/CORINAIR. 2009. Air pollutant emission inventory guidebook-2009. Agriculture. Technical report 9/ 2009. European Environment Agency.

[12] Vermorel, M., Jouany, J.P., Eugène, M., Sauvant, D., Noblet, J., Dourmad, J.Y. 2008. Quantitative evaluation of enteric $\mathrm{CH}_{4}$ emissions from livestock animals in 2007 in France (in French). INRA Prod. Anim. 21 (5), 403418.

[13] Berra, G., Finster, L., Valtorta, S. E. 2009. A simple technique for measuring enteric methane emissions in cows. FAVE-Veterinary science magazine 8 (1) 2009.

[14] DeRamus H.A., Clement T.C., Giampola D.D., Dickison P.C. 2003. Methane emissions of beef cattle on forages: efficiency of grazing management systems. Journal Environ Qual, 32: 269-277.

[15] Merino, P., Ramirez-Fanlo, E., Arriaga, H., del Hierro, O., A. Artetxe, M. Viguria. 2011. Regional inventory of methane and nitrous oxide emission from ruminant livestock in the Basque Country. Animal Feed Science and Technology. 166, 628-640.

[16] Fernández-Lorenzo, B., Dagnac, T., González-Arraez, A., Valladares, J., Perreira-Crespo, S., Flores, G. 2009. Milk production system in Galicia. 
Evolution and current status (in Spanish). Agricultural Research Center Mabegondo (CIAM). Pastos, (2) 251-294.

[17] IGE. 2004. Galician Institute of Statistics. Farm Cattle Registry. year 2003. http://www.ige.eu/web/mostrar_actividade_estatistica.jsp?idioma= gl\&codigo $=0301005$.

[18] Doreau, M., van der Werf, H. M. G., Micol, D., Dubroeucq, H., Agabriel, J., Rochette Y., Martin, C. 2011. Enteric methane production and greenhouse gases balance of diets differing in concentrate in the fattening phase of a beef production system. American Society of Animal Science.

[19] Gac, A., Béline, F., Bioteau, T., Maguet, K.. 2007. A French inventory of gaseous emissions $\left(\mathrm{CH}_{4}, \mathrm{~N}_{2} \mathrm{O}, \mathrm{NH}_{3}\right)$ from livestock manure management using a mass-flow approach. Livestock Science 112, 252-260.

[20] Hobbs, P.J., Webb, J., Mottram, T.T., Grant, B., Misselbrook, T.M. 2004. Emissions of volatile organic compounds originating from UK livestock agriculture. Journal of the Society of Food and Agriculture, 84, 14141420 .

[21] ESRI. 2008. Environmental Systems Research Institute. ArcGIS (geographic information systems software).

[22] EEA. EMEP/CORINAIR. 1999. Atmospheric Emission Inventory Guidebook, Second Edition, Copenhagen. European Environment Agency.

[23] CEIP, 2007. Methods and procedures for the technical review of air pollutant emission inventories reported under the convention and its protocols [online: http://www.ceip.at/review-of-inventories/].

[24] CEIP. 2010. Centre on Emission Inventories and Projections. Emissions as used in EMEP Models. Umweltbundesamt Vienna, Austria. http://www.ceip.at/ [online].

[25] CEIP. 2012. Centre on Emission Inventories and Projections. Emissions as used in EMEP Models. Umweltbundesamt Vienna, Austria. http://www.ceip.at/ [online].

[26] EEA. 2007. EMEP/CORINAIR Emission Inventory Guidebook-2007. Technical report No 16/2007. European Environment Agency.

[27] Dios, M., Morán, M., Carrera, F., Pombo, C., Souto, J.A., Casares, J.J., Díaz, A., Sáez, A., 2014. PRTRVal: a software tool for the validation of E-PRTR emissions data. International Journal of Environment and Pollution (in press).

[28] MARM, 2010. Public Information. Register of Emissions and Pollutant Sources. PRTR-Spain. Ministerio de Medio Ambiente, Medio Rural y Marino (MARM). http://www.prtr-es.es/informacion-publica/informacion-publica-, 15374,00,00.html.

[29] MARM. 2009. National Emissions Inventory of air pollutants. GHG Emissions by State government from Spanish inventory number 19902009. Ministry of Environment, Rural and Marine Affairs (MARM). 